\title{
Perceived Value of Green Residence: The Role of Perceived Newness and Perceived Relative Advantage
}

\begin{abstract}
Submitted 08/01/20, $1^{\text {st }}$ revision 12/02/20, $2^{\text {nd }}$ revision 29/03/20, accepted 14/05/20
Setyo Ferry Wibowo ${ }^{1}$, Gatot Nazir Ahmad ${ }^{2}$, Solekhah ${ }^{3}$

Abstract:

Purpose: This study develops an extension of the perceived value model by incorporating perceived product innovativeness. In this study, perceived innovativeness is conceptualized into two constructs: perceived newness and relative advantage. It examines whether these two constructs have an impact on both perceived value and purchase intention. The study also explores the effect of perceived price on perceived value and purchase intention.

Design/Approach/Methodology: To test our hypotheses, 498 participants responded to a questionnaire. Structural equation modelling was employed to evaluate the proposed research model.

Findings: The results demonstrate that (a) perceived newness plays an important role, having a positive indirect effect on purchase intention through perceived value; (b) perceived price also has a positive effect on perceived value and purchase intention; (c) there is no empirical evidence for the effect of relative advantage on perceived value and purchase intention.

Practical implication: Regards to the significant role of perceived newness and perceived price in determining perceived value and purchase intention of green residences, reducing consumers' uncertainty about the benefits offered by innovative products is a crucial task.

Originality/Value: While perceived innovativeness is generally regarded as a critical driver of purchase intention, current studies have paid little attention to the relation between associated benefits and consumers' perceived value. This is the first of the studies that examine the effect of perceived newness and relative advantage on perceived value and purchase intention in the context of green residences.
\end{abstract}

Keywords: Perceived newness, relative advantage, green innovation, green residence, perceived price, green perceived value, purchase intention.

JEL codes: $M 3, M 31$.

Paper type: Research article.

\footnotetext{
${ }^{1}$ Corresponding author, Universitas Negeri Jakarta, Jalan Rawamangun Muka, Indonesia, e-mail: setyoferry@unj.ac.id

${ }^{2}$ Universitas Negeri Jakarta, Jalan Rawamangun Muka, Indonesia,

e-mail: gnahmad@unj.ac.id

${ }^{3}$ Universitas Negeri Jakarta, Jalan Rawamangun Muka, Indonesia, e-mail: solekhah@unj.ac.id
} 


\section{Introduction}

Research on green product purchasing has increased over the past few years (Juan et al., 2017) due to the growing concern over the impact of consumption on the physical environment. Consumers are realizing the need for a move towards green products. Becoming green may appear to be expensive in the short term, but in the long run it will reduce consumer costs significantly. The concept of green products covers many areas, including food, clothes, electronic equipment, and buildings. The concept of green buildings includes green apartments, and focuses on improving the efficiency of resource use, including the use of energy, water, and various types of materials, in addition to minimizing the negative impact on the environment (Tam et al., 2012). Hu et al. (2014) define green housing as "environment-friendly, resourceefficient, energy-saving, health-improved, and comfortable-living housing". Customers are willing to pay extra if the perceived benefits of living in green residences are more beneficial than those from conventional buildings (ZalejskaJonsson, 2014).

Recently, the need has been recognized to understand the factors that influence residents' acceptance of green residential buildings (Liu et al., 2018). This is first because real estate plays a major role in affecting the environment (Deng et al., 2012). The construction industry, for example, is considered to produce a significant amount of carbon emissions (Tan and Goh, 2018). Second, green building, including green residentials, has become more popular in emerging countries, due to government regulatory pressure, the ease of information access, and resource mobility (Varia, 2015). The number of green buildings in Indonesia has increased by $20 \%$ in year 2015 (Varia, 2015).

In many developing countries, including Indonesia, green buildings are considered to be an innovation. Seng and Ping (2016) argue that studying innovation from the consumer's perspective should focus on consumer expectations and perceptions about innovative products. Therefore, exploring consumer's intention to purchase green residence from innovation framework is needed. However, the consumer purchase intention of green residential buildings in Indonesia has not been thoroughly investigated. The concern for green innovation in marketing studies has grown significantly during the past two decades (Peng and Liu, 2016). However, related knowledge has yet to be systematically integrated, so a clear picture of green innovation has not been articulated (Klewitz and Hansen, 2014).

Truong (2013) argues that the perceived value concept is relevant and provides a better understanding of consumer behaviour regarding innovation. However, perceived value has been underutilized in the innovation research area, and only a few recent studies have focused on the formation of perceived value in the context of new products (Rivière, 2015). To fill the gap in the literature, we develop a research model that utilizes Zeithaml's (1988) means-end model as the theoretical framework, thanks to the empirical evidence on its effectiveness to explain 
perceived value. We then extend the model by incorporating the concept of perceived innovation. Perceived innovation and perceived relative advantage serve as benefits that eventually determine the value of the innovation, since consumers' acceptance of a new offering is affected by how they perceive its newness and uniqueness (Lowe and Alpert, 2015). This study therefore aims to investigate the roles of perceived newness and relative advantage as predictors of perceived value and purchase intention. The integration is relevant since the green apartment is a product innovation that will yield positive results only when it has been accepted into the market and consumers have adopted it.

\section{Literature Review}

\section{Perceived Value:}

The concept of 'consumer value' has become the central topic to be addressed in every marketing activity. Leão and Mello (2007) describe customer value as the best concept to analyze consumer behaviour and decision-making. The central argument of customer value is on understanding and summarizing customer expectations; generating and delivering desired customer experiences; and also evaluating and managing customer evaluation (Paananen and Seppänen, 2013).

Customer value studies rely on the idea of cost versus benefits (Payne and Holt, 2001). Perhaps the most widely cited definition of perceived value is from Zeithaml (1988): "perceived value is the consumer's overall assessment of the utility of a product based on perceptions of what is received and what is given." In the context of green marketing, Chen and Chang (2012) describe green perceived value as "a consumer's overall appraisal of the net benefit of a product or service between what is received and what is given based on the consumer's environmental desires, sustainable expectations, and green needs."

\section{Perceived Newness and Relative Advantage as the Dimensions of Innovativeness:}

According to Ledwith and O'Dwyer (2009), in the development of a new product, success is measured by how consumers perceive the innovation, which leads to their acceptance of it. Agarwal and Prasad (1998) state that perceived innovation will affect consumer behaviour in adopting innovation, while Lafferty and Goldsmith (2004) point out the importance of perceived innovativeness in attracting consumers and encouraging them to buy the product. However, there is a lack of studies which investigate innovation from the consumer's viewpoint (Shams et al., 2015).

Perceived innovativeness is "the perceived degree of newness and improvement over existing alternatives" (Lowe and Alpert, 2015). However, how consumers perceive innovation is still debatable. According to Rogers (2010), one of the important aspects of the adoption of innovation is consumers' perceived attributes of innovation, which consist of profit or its relative advantage, compatibility, complexity, trialability, and observability. However, Moore and Benbasat (1991) and Stachewicz (2011) state that the key to the success of the diffusion of 
innovation is its perceived use. Shams et al. (2015) classify various attributes or indicators of perceived innovation into two dimensions, namely newness and usefulness, or meaningfulness.

In our case, usefulness or meaningfulness represent the relative advantage of the innovation. Therefore, the study employs newness and relative advantage as the attributes of perceived innovativeness. Furthermore, we treat perceived newness and relative advantage as separate constructs to predict consumers' perceived value, supporting another perspective that suggests the attributes of innovation are the determinants rather than the dimensions of perceived innovativeness (Hoyer and MacInnis, 2008). Perceived newness has been defined in a variety of ways but represents the same construct. Product newness is "the extent to which the new product is compatible with the experiences and consumption patterns of potential customers" (Atuahene-Gima, 1995). Morman and Miner (1997) associate newness with creativity, while Olshavsky and Spreng (1996) emphasise innovation continuity. Blake et al. (2007) underline novelty and recency as the characteristics of newness, while Alexander et al. (2008) and Hoeffler (2003) measured the continuum of the newness, from the incrementally new product (INP) to the really new product (RNP), and its impact on perceived uncertainty and the intention to adopt the innovation.

Lowe and Alpert (2015) suggest that innovation should offer a relative advantage for consumers in order for them to translate it into purchase intention. Relative advantage is the perceived benefit, which is described as "the degree to which an innovation is perceived as superior to the idea it supersedes" (Rijsdijk and Hultink, 2009). Tornatzky and Klein (1982) explain that consumers perceive a wide area of advantages, includes economic profitability, social benefit, and time-saving. A systematic review by Kapoor et al. (2014) concludes that among other attributes of innovation, relative advantage makes the highest contribution. Four potential sources of value may be detected and matched with more traditional notions of value; functional advantage, economic advantage, social advantage, and learning costs advantage (Rogers, 1995).

\section{Perceived Price:}

Hasan et al. (2018) identify price is a substantial barrier to green purchasing behaviour. From the consumers' point of view, price represents a sacrifice they make to obtain a product. Perceived price is the perception consumers have towards the objective price. Typical indicators used to measure perceived price are price fairness, cheapness-expensiveness of price, and price-quality relationship.

\section{Conceptual Development}

Green Perceived Newness and Purchase Intention:

Betz (2003) states that the decision to use innovation is affected by perceived risks, including the impact on the environment from the production process, product usage, 
and product disposal. The importance of green innovation has been mentioned in previous studies. Agarwal and Prasad (1998) argue that perception of new products in terms of relative advantage, ease of use, and compatibility will affect the intention to use them. The two dimensions of perceived product innovativeness, newness and usefulness, will be translated into purchase intention (Lowe and Alpert, 2015). Hoe et al. (2018) found that the emotional value of benefit significantly affects the purchase intention of residential property. Based on these arguments, we posit the following hypothesis:

$H_{1}$ : Green perceived newness positively affects purchase intention.

$\mathrm{H}_{2}$ : Green relative advantage positively affects purchase intention.

Green Perceived Newness, Relative Advantage, and Green Perceived Value:

Maria et al. (2013) argue that failure of green innovation is often caused by innovation, which gives little or no benefit to consumers. Lowe and Alpert (2015) suggest two forms of benefit; newness, and relative advantage. Newness will affect the affective or emotional dimension by creating a "wow" response. For the purchase behaviour of smart watches, the perceived relative advantage represents the quality features of the product, which will affect consumers' attitude and value (Hsiao and Chen, 2018). Kim and Baek (2018) argue that time convenience, which represents the relative advantage of a mobile app, significantly affects the perceived value. The greater the relative advantage, the more consumers will perceive the value of the product. Therefore, the resulting hypotheses are:

$H_{3}:$ Green perceived newness positively affects green perceived value.

$H_{4}$ : Green perceived relative advantage positively affects green perceived value.

\section{Perceived Price and Perceived Value:}

As perceived value is a comparison between what it gets and what to give, Zeithaml (1988) proposes price as one consumer sacrifice, among others. Since perceived value is a tradeoff between quality and price, perceived price will lead to the formation of value for money (Sweeney and Soutar, 2001). Therefore, the related hypothesis is:

$H_{5}$ : Perceived price positively affects green perceived value.

\section{Perceived Price and Purchase Intention:}

Financial factors account for almost 30 percent of the income decisions when people purchase a house (Reed and Mills, 2007). Abdullah et al. (2012) found that such factors ranked second after locational ones in their influence on first-time home buyers' decisions in Malaysia. Yoke et al. (2018) proved the significant effect of financial factors as a predictor of pro-environmental housing in Malaysia. Therefore, the following hypothesis is proposed:

$H_{6}:$ Perceived price positively affects purchase intention. 
Green Perceived Value and Purchase Intention:

According to Zeithaml (1988), consumers tend to buy products that have a higher value. Zeithaml's (1998) model has a direct effect on purchase intention (Lundgren, 2013), allowing for both benefits and sacrifices to be included in any action that increases customer value (Klanac, 2013). Wu and Chang (2016) found a significant effect of both functional and emotional value on purchase intention. Yadav and Pathak (2017) modified the TPB model by including perceived value as the predictor of purchase intention of green products, with significant results. Chen and Chang (2012) found that green perceived value is a substantial determinant of green purchase intention. Based on these arguments, we propose the hypothesis that:

\section{H7: Green perceived value positively affects purchase intention.}

\section{Methododology}

A survey was conducted of 500 people in five cities in Indonesia which were considering purchasing of a resident, which were claimed by their developers to be green residences. The respondents were selected using purposive sampling method. The questionnaire as the instrument was developed based on the literature review to cover the items relating to the constructs. For each variable pertaining to these measures, the respondents were asked to indicate their agreement with each statement using a five-point Likert scale $(1=$ strongly disagree; $5=$ strongly agree $)$. Convenience sampling was used in this study. An offline survey was conducted and resulted a high-level response rate, which was $99.6 \%$ (498 respondents).

The survey questionnaire consisted of six parts: (1) perceived newness, (2) relative advantage, (3) perceived price, (4) perceived value, (5) purchase intention, and (6) demographic information. Perceived newness was measured using six items adapted from previous studies (Shams et al., 2015; Wu and Chen, 2014), perceived relative advantage was measured using four items adapted from Stachewicz (2011), perceived price was measured using six items adapted from $\mathrm{Wu}$ and Chen (2014), perceived value was measured using three items adapted from previous studies (Hewitt et al., 2016; Monroe, 1990; Wu and Chen, 2014), and purchase intention was measured using four items adapted from Lee (2017). The scale items were measured using a 5-point Likert scale, on which the respondents indicated the extent to which they agreed or disagreed with the statements. Factor analysis was applied to ascertain valid items. Reliability was tested using Cronbach Alpha reliability statistics, and structural equation models (SEMs) were employed to test model fitness and for hypothesis testing.

\section{Results}

\section{Respondent Profile:}

The ages of most respondents ranged from 31 to 45 years old (67.9\%). The proportion of male respondents was $47.6 \%$, with that of females $52.4 \%$. More than 
half of the respondents $(53 \%)$ were middle managers. The percentage of those who claimed their apartment as their primary residence was $50.7 \%$. 65.4\%. held an undergraduate degree and $56 \%$ claimed that environmental friendliness was one of their primary considerations after price and location.

Validity and Reliability Results:

The factor analysis results show that for purchase intention, perceived newness, and perceived value, all the indicators can be used to measure the variables. However, for perceived price, pp3, pp5, and pp6 were deleted, and for relative advantage ra4 was deleted since the value of factor loadings are below .50. For the remaining items, convergent validity performed with factor loadings exceeding .50. However, the score of the average variance extracted (AVE) for perceived newness was under .50. All the variables achieved composite reliability, with CR scores above .70. In addition, the Cronbach's alpha scores for all the variables exceeded .60, indicating that the instrument had the required reliability (Table 1).

Table 1. Results of the Validity and Reliability Tests

\begin{tabular}{|c|c|c|c|c|c|c|}
\hline & $\begin{array}{l}\text { Loading } \\
\text { Factor }\end{array}$ & $\begin{array}{l}\text { Bartlett's Test } \\
\text { of Sphericity }\end{array}$ & $\mathrm{KMO}$ & $\begin{array}{c}\alpha \\
\text { Cronbach }\end{array}$ & AVE & $\mathrm{CR}$ \\
\hline Minimum & .5 & .005 & .5 & .6 & .5 & .7 \\
\hline Acceptance Value & & & & & & \\
\hline Purchase Intention & & .000 & .857 & $\alpha=.837$ & .507 & .877 \\
\hline pi1 & .739 & & & & & \\
\hline pi2 & .720 & & & & & \\
\hline pi3 & .718 & & & & & \\
\hline pi4 & .789 & & & & & \\
\hline pi5 & .706 & & & & & \\
\hline pi6 & 699 & & & & & \\
\hline pi7 & .604 & & & & & \\
\hline Perceived Newness & & .000 & .727 & $\alpha=.693$ & .395 & 0,796 \\
\hline pn1 & .558 & & & & & \\
\hline pn2 & .679 & & & & & \\
\hline pn3 & 608 & & & & & \\
\hline pn4 & .629 & & & & & \\
\hline pn5 & 663 & & & & & \\
\hline pn6 & 627 & & & & & \\
\hline Perceived Price & & .000 & .657 & $\alpha=.794$ & .556 & .788 \\
\hline $\mathrm{pp} 1$ & .713 & & & & & \\
\hline pp2 & .822 & & & & & \\
\hline pp3 & .345 & & & & & \\
\hline pp4 & 696 & & & & & \\
\hline $\mathrm{pp} 5$ & 479 & & & & & \\
\hline pp6 & 470 & & & & & \\
\hline Perceived Value & & .000 & .640 & $\alpha=.691$ & .619 & .829 \\
\hline pv1 & .769 & & & & & \\
\hline pv2 & .843 & & & & & \\
\hline pv3 & .746 & & & & & \\
\hline Relative Advantage & & .000 & .688 & $\alpha=.737$ & .634 & .838 \\
\hline ral & .812 & & & & & \\
\hline $\mathrm{ra} 2$ & .815 & & & & & \\
\hline ra3 & .762 & & & & & \\
\hline
\end{tabular}




\section{Source: Authors.}

Goodness of Fit of the Research Model:

For the goodness of fit, the results show that the measurement model had an adequate fit, demonstrating a match between the data and the model based on the results as follows: for the measurement model test results the model is fit at a probability value of .083, with an CMIN/DF score of 1.413 , CFI score of .984, and RMSEA score of .029.

\section{Structural Model Test Results:}

The path significance results of the research hypotheses are shown in Table 2 and Figure 2.

Table 2. Hypothesis testing results

\begin{tabular}{|c|c|c|c|c|c|c|}
\hline $\mathrm{H}_{1}$ & Perceived newness & $\rightarrow$ & Purchase intention & $\begin{array}{r}\text { C.R. } \\
1.101\end{array}$ & $\begin{array}{c}\mathrm{P} \\
.271\end{array}$ & $\begin{array}{l}\text { Results } \\
\text { Rejected }\end{array}$ \\
\hline $\mathrm{H}_{3}$ & Perceived newness & $\rightarrow$ & Perceived value & 3.291 & $* * *$ & Accepted \\
\hline $\mathrm{H}_{2}$ & Relative advantage & $\rightarrow$ & Purchase intention & .572 & .567 & Rejected \\
\hline $\mathrm{H}_{4}$ & Relative advantage & $\rightarrow$ & Perceived value & .949 & .342 & Rejected \\
\hline $\mathrm{H}_{5}$ & Perceived price & $\rightarrow$ & Perceived value & 3.132 & .002 & Accepted \\
\hline $\mathrm{H}_{6}$ & Perceived price & $\rightarrow$ & Purchase intention & 2.885 & .004 & Accepted \\
\hline $\mathrm{H}_{7}$ & Perceived value & $\rightarrow$ & Purchase intention & 2.047 & .041 & Accepted \\
\hline
\end{tabular}

\section{Source: Authors.}

Figure 2. Results of the Structural Model Test

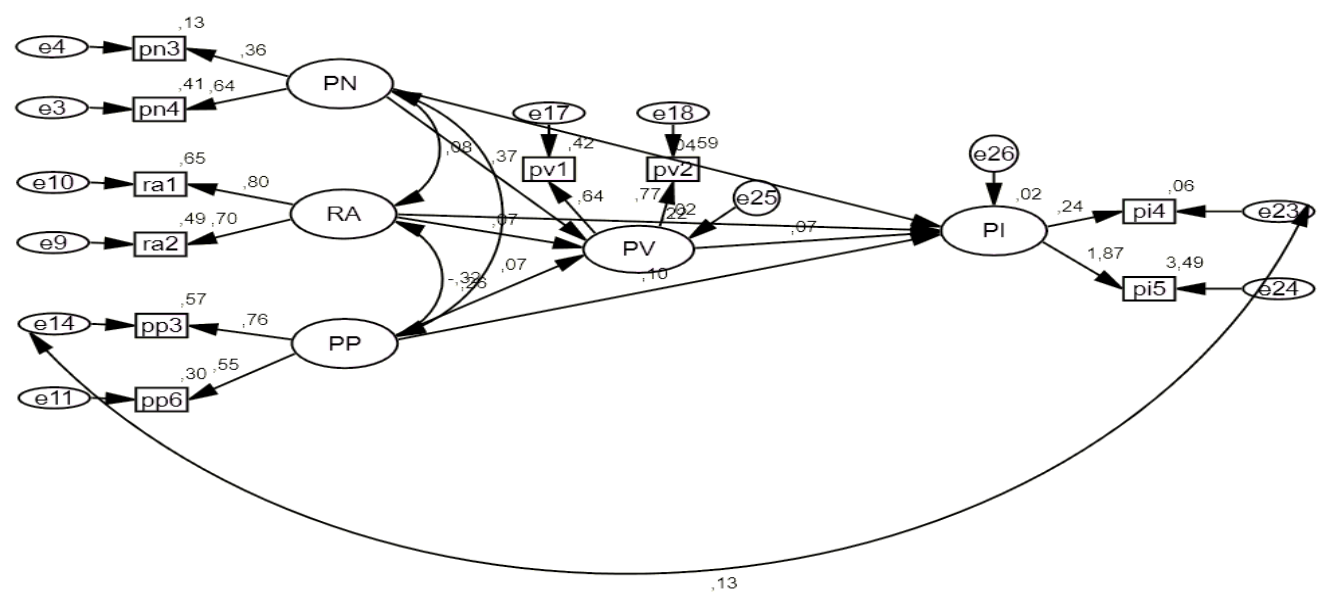

Source: Authors.

Based on Table 2 and Figure 2 above, $\mathrm{H}_{2}, \mathrm{H}_{5}$ and $\mathrm{H}_{6}$, and $\mathrm{H}_{7}$ are accepted. Therefore, purchase intention is proven to be predicted by perceived value (with a coefficient score of .072) and perceived price (coefficient score of .10). In addition, perceived value is affected by perceived newness (with a coefficient score of .371) and 
perceived price (coefficient score of .265). Perceived newness is not proven to have a direct effect on purchase intention. However, the indirect effect of perceived newness on purchase intention is proven to be mediated by perceived value (coefficient score of .164). There is no empirical evidence for the effect of relative advantage on purchase intention, and surprisingly the effect of relative advantage on perceived value as well.

\section{Discussion}

Perceived price is proven to have an impact on purchase intention, a finding which supports Wang et al. (2008). Perceived price also affects perceived value, which also supports previous studies (Choi et al., 2013). We also find that perceived product newness and perceived price are positively related to perceived value, which is in line with other studies (Dinnin, 2009; Wang et al., 2008). We also find that perceived value is positively related to purchase intention. Our findings support robust evidence from previous studies of the relationship between perceived value and purchase intention (Ponte et al., 2015; Wu and Yu-Chen, 2014).

However, we find that perceived product newness is not related directly to purchase intention with respect to green residence. This result supports the insignificant results of other previous studies which investigate the effect of perceived product innovativeness on purchase intention (Li et al., 2015; Wu and Chen, 2014), but is in contrast to the findings of Jeong et al. (2017). This supports our argument on the importance of the perceived value concept in explaining consumers' choice. Even when consumers gain benefits in terms of a positive affective response towards the novelty and recency of the green residence concept, this will not directly influence their choice. Comparing this benefit with price will determine the perceived value of the green residences and will eventually affect consumers' purchase intention.

We also failed to prove the effect of relative advantage, both on perceived value and purchase intention. The results contrast with those of previous studies (Baird and Raghu, 2015; Kapoor et al., 2014). We argue that this result was caused by the uncertainty of consumers towards the benefits or advantages offered by green residence. This is supported by Hoeffler (2002), which found that those who viewed the low uncertainty positioning of benefits or attributes had higher purchase intention levels.

The findings prove the strategic contribution of perceived value in determining behavioural intention, particularly for innovative products. No matter how attractive the newness of innovative products, consumers will always compare this newness benefit with the price they must pay for the products. Furthermore, consumers will not rely solely on the benefits of newness, but also on the meaningfulness or the advantage of the product compare to its predecessors. However, it is important to note that consumers tend to have a high level of uncertainty over the advantages, since the innovative products are not familiar to them yet. Therefore, reducing 
consumers' uncertainty about the benefits offered by innovative products is a crucial task.

This study makes a theoretical contribution to understanding the role of perceived value in the purchase intention of green residence as an innovative product. Elaboration has been made on perceived product newness and relative advantage, as elements of innovation attributes, in addition to perceived price, in forming perceived value, which in turn predicts green purchase intention by Indonesian consumers.

\section{Conclusion}

Green residence has recently started to attract attention, but the drivers of the actual adoption of it need to be investigated further. Recent studies have explored green residence as an innovative product and explored the determinants of its purchase intention. This study integrates the perceived value and innovation frameworks to capture how consumers perceive the value of green residential as an innovative product in order to explain their intentional behaviour.

The results of the study reveal the important role of green product newness, perceived price, and green perceived value in predicting green purchase intention. In particular, the study confirms the important contribution of green perceived newness to the adoption of green products. It also demonstrates that green perceived newness indirectly influences green purchase intention positively via green perceived value.

Despite its potential to effectively predict consumers' purchase intention of green residence, the study has some limitations that should be regarded as opportunities for future research. First, it does not fully incorporate elements of perceived sacrifice and only uses perceived price as representative of consumer sacrifice. For further investigation, it is also suggested to include other types of monetary and nonmonetary sacrifices. Second, with regards to our argument about the role of consumer uncertainty in relative advantage, it would be valuable if future studies were to place the model into the greenwash area.

\section{References:}

Abdullah, L., Nor, S., Jumadi, S.N., Arshad, S.H. 2012. First-time home buyers: Factors influencing decision making. International Conference on Innovation and Technology for Sustainable Built Environment, 249-254.

Agarwal, R., Prasad, J. 1998. A conceptual and operational definition of personal innovativeness in the domain of information technology. Information Systems Research, 9(2), 204-215. https://doi.org/https://doi.org/10.1287/isre.9.2.204.

Alexander, D.L., Lynch Jr, J.G., Wang, Q. 2008. As time goes by: Do cold feet follow warm intentions for really new versus incrementally new products? Journal of Marketing Research, 45(3), 307-319. https://doi.org/https://doi.org/10.1509/jmkr.45.3.307.

Atuahene-Gima, K. 1995. An exploratory analysis of the impact of market orientation on 
new product performance: a contingency approach. Journal of Product Innovation Management: An International Publication of the Product Development and Management Association, 12(4), 275-293. https://doi.org/https://doi.org/10.1111/1540-5885.1240275.

Baird, A., Raghu, T.S. 2015. Associating consumer perceived value with business models for digital services. European Journal of Information Systems, 24(1), 4-22. https://doi.org/https://doi.org/10.1057/ejis.2013.12.

Betz, F. 2003. Managing technological innovation: competitive advantage from change. John Wiley and Sons.

Blake, B.F., Valdiserri, C.M., Neuendorf, K.A., Valdiserri, J.N. 2007. The online shopping profile in the cross-national context: The roles of innovativeness and perceived innovation newness. Journal of International Consumer Marketing, 19(3), 23-51. https://doi.org/https://doi.org/10.1300/j046v19n03_03.

Chen, Y.S., Chang, C.H. 2012. Enhance green purchase intentions: The roles of green perceived value, green perceived risk, and green trust. Management Decision, 50(3), 502-520. https://doi.org/https://doi.org/10.1108/00251741211216250.

Choi, W.S., Choi, S.K., Lee, S.B. 2013. The effects of the attributes of the eco-friendly agricultural products traceability system on perceived value and behavioral intention. Culinary Science and Hospitality Research, 19(4), 161-175. https://doi.org/https://doi.org/10.20878/cshr.2013.19.4.012012012

Deng, Y., Li, Z., Quigley, J.M. 2012. Economic returns to energy-efficient investments in the housing market: evidence from Singapore. Regional Science and Urban Economics, 42(3), 506-515. https://doi.org/https://doi.org/10.2139/ssrn.1672364.

Dinnin, A. 2009. The appeal of our new stuff: How newness creates value. NA-Advances in Consumer Research Volume, 36, 261-265.

Hasan, A., Irfan, R., Shaari, Z.H., Sharif, M.A.M. 2018. Consumers' Perception of Barriers Effecting Green Purchase Behavior: Instrument Assessment. SHS Web of Conferences, 56.

Hewitt, E.L., Andrews, C.J., Senick, J.A., Wener, R.E., Krogmann, U., Sorensen Allacci, M. 2016. Distinguishing between green building occupants' reasoned and unplanned behaviours. Building Research and Information, 44(2), 119-134. https://doi.org/https://doi.org/10.1080/09613218.2015.1015854.

Hoe, J., Dastane, O., Selvaraj, K. 2018. Predicting Consumer Perception and its Impact on Purchase Intention for Residential Property Market. Journal of Technology Management and Business, 5(2), 59-77. https://doi.org/https://doi.org/10.30880/jtmb.2018.05.02.007.

Hoeffler, S. 2003. Measuring preferences for really new products. Journal of Marketing Research, 40(4), 406-420. https://doi.org/https://doi.org/10.1509/jmkr.40.4.406.19394.

Hoeffler, S. 2002. Conceptualizing newness and positioning really new products. NAAdvances in Consumer Research Volume 29, 267.

Hoyer, W.D., MacInnis, D.J. 2008. Consumer Behavior (5th ed.). Cengage Learning. https://books.google.co.id/books?id=fk1rTxRYtY0C.

Hsiao, K.L., Chen, C.C. 2018. What drives smartwatch purchase intention? Perspectives from hardware, software, design, and value. Telematics and Informatics, 35(1), 103113. https://doi.org/https://doi.org/10.1016/j.tele.2017.10.002.

Hu, H., Geertman, S., Hooimeijer, P. 2014. The willingness to pay for green apartments: The case of Nanjing, China. Urban Studies, 51(16), 3459-3478. https://doi.org/https://doi.org/10.1177/0042098013516686. 
Jeong, S.C., Kim, S.H., Park, J.Y., Choi, B. 2017. Domain-specific innovativeness and new product adoption: A case of wearable devices. Telematics and Informatics, 34(5), 399-412. https://doi.org/https://doi.org/10.1016/j.tele.2016.09.001.

Juan, Y.K., Hsu, Y.H., Xie, X. 2017. Identifying customer behavioral factors and price premiums of green building purchasing. Industrial Marketing Management, 64, 3643. https://doi.org/https://doi.org/10.1016/j.indmarman.2017.03.004.

Kapoor, K.K., Dwivedi, Y.K., Williams, M.D. 2014. Rogers' innovation adoption attributes: A systematic review and synthesis of existing research. Information Systems Management, 31(1), 74-91. https://doi.org/https://doi.org/10.1080/10580530.2014.854103.

Kim, S., Baek, T.H. 2018. Examining the antecedents and consequences of mobile app engagement. Telematics and Informatics, 35(1), 148-158. https://doi.org/https://doi.org/10.1016/j.tele.2017.10.008.

Klanac, N.G. 2013. An integrated approach to customer value: A comprehensive-practical approach. Jbm-Journal of Business Market Management, 6(1), 22-37.

Klewitz, J., Hansen, E.G. 2014. Sustainability-oriented innovation of SMEs: a systematic review. Journal of Cleaner Production, 65, 57-75. https://doi.org/https://doi.org/10.1016/j.jclepro.2013.07.017.

Lafferty, B.A., Goldsmith, R.E. 2004. How influential are corporate credibility and endorser attractiveness when innovators react to advertisements for a new high-technology product? Corporate Reputation Review, 7(1), 24-36. https://doi.org/https://doi.org/10.1057/palgrave.crr.1540209.

Leão, A.L.M.de.S., Mello, S.C.B.de. 2007. The means-end approach to understanding customer values of a on-line newspaper. BAR - Brazilian Administration Review, 4(1), 1-20. https://doi.org/https://doi.org/10.1590/s1807-76922007000100002.

Ledwith, A., O’Dwyer, M. 2009. Market Orientation, NPD Performance, and Organizational Performance in Small Firms. Journal of Product Innovation Management, 26(6), 652-661. https://doi.org/10.1111/j.1540-5885.2009.00690.x.

Lee, Y.K. 2017. A comparative study of green purchase Intention between Korean and Chinese consumers: The moderating role of collectivism. Sustainability, 9(10), 1930. https://doi.org/https://doi.org/10.3390/su9101930.

Li, G., Zhang, R., Wang, C. 2015. The role of product originality, usefulness and motivated consumer innovativeness in new product adoption intentions. Journal of Product Innovation Management, 32(2), 214-223. https://doi.org/10.1111/jpim.12169.

Liu, Y., Hong, Z., Zhu, J., Yan, J., Qi, J., Liu, P. 2018. Promoting green residential buildings: Residents' environmental attitude, subjective knowledge, and social trust matter. Energy Policy, 112, 152-161. https://doi.org/https://doi.org/10.1016/j.enpol.2017.10.020.

Lowe, B., Alpert, F. 2015. Forecasting consumer perception of innovativeness.

Technovation, 45, 1-14. https://doi.org/https://doi.org/10.1016/j.technovation.2015.02.001.

Lundgren, B. 2013. Customer-perceived Value in Residential Developments: the Case of Hornsberg Strand, Sweden. International Real Estate Review, 16(1), 1-27.

Maria, I., Freitas, B., Fontana, R., Adams, P. 2013. Strategic orientations, marketing capabilities and innovation: an empirical investigation. 35th DRUID Celebration Conference, 1-28.

Monroe, K.B. 1990. Pricing: Making Profitable Decisions. McGraw-Hill.

Moore, G.C., Benbasat, I. 1991. Development of an instrument to measure the perceptions of 
adopting an information technology innovation. Information Systems Research, 2(3), 192-222. https://doi.org/https://doi.org/10.1287/isre.2.3.192.

Moorman, C., Miner, A.S. 1997. The impact of organizational memory on new product performance and creativity. Journal of Marketing Research, 34(1), 91-106. https://doi.org/https://doi.org/10.1177/002224379703400108.

Olshavsky, R.W., Spreng, R.A. 1996. An exploratory study of the innovation evaluation process. Journal of Product Innovation Management, 13(6), 512-529. https://doi.org/https://doi.org/10.1111/1540-5885.1360512.

Paananen, A., Seppänen, M. 2013. Reviewing customer value literature: Comparing and contrasting customer values perspectives. Intangible Capital, 9(3), 708-729. https://doi.org/https://doi.org/10.3926/ic.389.

Payne, A., Holt, S. 2001. Diagnosing customer value: integrating the value process and relationship marketing. British Journal of Management, 12(2), 159-182. https://doi.org/https://doi.org/10.1111/1467-8551.00192.

Peng, X., Liu, Y. 2016. Behind eco-innovation: Managerial environmental awareness and external resource acquisition. Journal of Cleaner Production, 139, 347-360. https://doi.org/https://doi.org/10.1016/j.jclepro.2016.08.051.

Ponte, E.B., Carvajal-Trujillo, E., Escobar-Rodríguez, T. 2015. Influence of trust and perceived value on the intention to purchase travel online: Integrating the effects of assurance on trust antecedents. Tourism Management, 47, 286-302. https://doi.org/https://doi.org/10.1016/j.tourman.2014.10.009.

Reed, R., Mills, A. 2007. Identifying the drivers behind housing preferences of first-time owners. Property Management, 25(3), 225-241. https://doi.org/https://doi.org/10.1108/02637470710753611.

Rijsdijk, S.A., Hultink, E.J. 2009. How today's consumers perceive tomorrow's smart products. Journal of Product Innovation Management, 26(1), 24-42. https://doi.org/https://doi.org/10.1111/j.1540-5885.2009.00332.x.

Rivière, A. 2015. Towards a model of the perceived value of innovation: The key role of perceived benefits ahead of the adoption process. Recherche et Applications En Marketing (English Edition), 30(1), 5-27. https://doi.org/https://doi.org/10.1177/2051570714560317.

Rogers, E. 1995. Diffusion of innovations (4th ed.). Free Press.

Rogers, E. 2010. Diffusion of Innovations, 4th Edition (4th ed.). Free Press. https://books.google.co.id/books?id=v1ii4QsB7jIC.

Seng, L.C., Ping, N.S. 2016. The Influence of Product Innovation Toward Consumer Purchase Intention. International Journal of Economics, Commerce and Management, 4(4), 773-782.

Shams, R., Alpert, F., Brown, M. 2015. Consumer perceived brand innovativeness: conceptualization and operationalization. European Journal of Marketing, 49(9/10), 1589-1615. https://doi.org/https://doi.org/10.1108/ejm-05-2013-0240.

Stachewicz, A.B. 2011. Measuring the perceived attributes of innovation: A study of capacitive switch technology in industrially designed user interface controls. $\mathrm{http} / / /$ commons.emich.edu/cgi/viewcontent.cgi?article=1359andcontext=theses.

Sweeney, J.C., Soutar, G.N. 2001. Consumer perceived value: The development of a multiple item scale. Journal of Retailing, 77(2), 203-220. https://doi.org/https://doi.org/10.1016/s0022-4359(01)00041-0.

Tam, V.W.Y., Hao, J.L., Zeng, S.X. 2012. What affects implementation of green buildings? 
An empirical study in Hong Kong. International Journal of Strategic Property Management, 16(2), 115-125. https://doi.org/https://doi.org/10.3846/1648715x.2011.645559.

Tan, W.L., Goh, Y.N. 2018. The role of psychological factors in influencing consumer purchase intention towards green residential building. International Journal of Housing Markets and Analysis, 11(5), 788-807. https://doi.org/10.1108/IJHMA-112017-0097.

Tornatzky, L.G., Klein, K.J. 1982. Innovation characteristics and innovation adoptionimplementation: A meta-analysis of findings. IEEE Transactions on Engineering Management, 29(1), 28-45. https://doi.org/https://doi.org/10.1109/tem.1982.6447463.

Truong, Y. 2013. A cross-country study of consumer innovativeness and technological service innovation. Journal of Retailing and Consumer Services, 20(1), 130-137. https://doi.org/https://doi.org/10.1016/j.jretconser.2012.10.014.

Varia. 2015. Green Building’ Primadona Pasar Bebas ASEAN. Varia. http://www.varia.id/2015/01/21/green-building-primadona-pasar-bebas-asean/.

Wang, Q., Dacko, S., Gad, M. 2008. Factors influencing consumers' evaluation and adoption intention of really-new products or services: prior knowledge, innovativeness and timing of product evaluation. NA - Advances in Consumer Research Volume 35, 416-422.

Wu, S.I., Chang, H.L. 2016. The Model of Relationship between the Perceived Values and the Purchase Behaviors toward Innovative Products. Journal of Management and Strategy, 7(2), 31. https://doi.org/https://doi.org/10.5430/jms.v7n2p31.

$\mathrm{Wu}$, S.I., Chen, Y.J. 2014. The impact of green marketing and perceived innovation on purchase intention for green products. International Journal of Marketing Studies, 6(5), 81-100. https://doi.org/https://doi.org/10.5539/ijms.v6n5p81.

$\mathrm{Wu}$, S.I., Yu-Chen, W. 2014. The influence of enterprisers' green management awareness on green management strategy and organizational performance. The International Journal of Quality and Reliability Management, 31(4), 455-476. https://search.proquest.com/docview/1507645208? accountid=32819.

Yadav, R., Pathak, G.S. 2017. Determinants of consumers' green purchase behavior in a developing nation: Applying and extending the theory of planned behavior. Ecological Economics, 134, 114-122. https://doi.org/https://doi.org/10.1016/j.ecolecon.2016.12.019.

Yoke, C.C., Mun, Y.W., Peng, L.M., Yean, U.L. 2018. Purchase Intention of Residential Property in Greater Kuala Lumpur, Malaysia. International Journal of Asian Social Science, 8(8), 580-590. https://doi.org/https://doi.org/10.18488/journal.1.2018.88.580.590.

Zalejska-Jonsson, A. 2014. Stated WTP and rational WTP: Willingness to pay for green apartments in Sweden. Sustainable Cities and Society, 13, 46-56. https://doi.org/https://doi.org/10.1016/j.scs.2014.04.007.

Zeithaml, V.A. 1988. Consumer Perceptions of Price, Quality, and Value: A Means-End Model and Synthesis of Evidence. Journal of Marketing Theory, 52(3), 2-22. https://doi.org/https://doi.org/10.1177/002224298805200302. 